\title{
Responsibility Accounting and Profitability of Listed Companies in Nigeria
}

\author{
Adegbie Folajimi Festus, Urewa Ochai-Adejoh, Owolabi Babatunde Ayodeji \\ Department of Accounting, School of Management Sciences, Babcock University, Ilishan-Remo, Ogun State, Nigeria \\ Email address: \\ adegbief@babcock.edu.ng (A. F. Festus), urewaocheja@yahoo.com (U. Ochai-Adejoh), owolabiayodeji83@yahoo.com (O. B. Ayodeji)
}

\section{To cite this article:}

Adegbie Folajimi Festus, Urewa Ochai-Adejoh, Owolabi Babatunde Ayodeji. Responsibility Accounting and Profitability of Listed Companies in Nigeria. International Journal of Accounting, Finance and Risk Management. Vol. 5, No. 2, 2020, pp. 101-117. doi: $10.11648 /$ j.ijafrm.20200502.15

Received: February 24, 2020; Accepted: April 13, 2020; Published: May 28, 2020

\begin{abstract}
Structuring activities into responsibility centers and optimization of resource is a priority in meeting investors' performance and profitability expectations in both small and large organizations. Studies have shown that to meet these expectations, adequate performance evaluation and reward system are managers' challenges. This study investigated the effect of responsibility accounting on profitability of listed companies in Nigeria. Ex-post facto research design was adopted. The population was 173 quoted companies on the Nigerian Stock Exchange as at 31st December 2016. Ten companies were selected using stratified and purposive sampling technique. Data were extracted from published financial statements of sampled companies; validity and reliability of the data were premised on the scrutiny of the external auditors. Descriptive and inferential (Panel data regression) statistics were used to analyze the data. The study revealed that profitability measured by NPBT, of listed companies in Nigeria is significantly influenced by responsibility accounting (RA), F-Stat $=114.56, A d j R^{2}=.0 .6964, p=0.000$. There is no significant difference in the result of NPBT with and without the control variable of firm size. The result with control variables revealed F-Stat $=87.63 ; \operatorname{Adj}^{2}=0.7242 ; P=0.000$. The study also revealed that RA had a positive significant relationship with EPS with control variables of firm size, $F$-Stat $=6.56, A d j R^{2}=0.1442 ; P=0.000$. However, without control variables, no significant effect of responsibility accounting on EPS was observed as shown in the following result: $F-S t a t=0.45, A d j R^{2}=-0.0112, p=0.64$. Furthermore, the study revealed that profitability measured by ROA exhibited an insignificant relationship with RA given the following results, $A d j R^{2}=0.0089 ; P=0.000$. RA with control variables of firm size, insignificantly affected ROA while Firm Size exerted significant positive effect on ROA (as the size of the firm changes by a unit, ROA increased by $23.9 \%$ as seen in model $3 \mathrm{~b}$ ) given the following result: $A d j R^{2}=0.0399 ; P=0.782$. This study concluded that responsibility accounting had an influence on profitability of listed companies in Nigeria. The study recommended that since profitability is the whole essence of responsibility accounting, managers should ensure delegation of task with responsibilities clearly spelt out, regular appraisal process, achievable project budgeting, instituting cross functional teams and efficient reward systems put in place towards achieving the corporate objective that would influence better profitability.
\end{abstract}

Keywords: Activity Centers, Decentralization, Evaluations, Profitability, Responsibility Accounting

\section{Introduction}

\subsection{Background to the Study}

Umobong [52] averred that the primary motive of business operations is to have returns and economic value from investments, and as such only profit generating capability activities can guarantee a continuous going concern for companies. Therefore, the existence and survival of businesses largely depend on the achievement of profitability objective of the organization. Hanini [24] posited that business failures are common factors in the real business cycle if proper functioning and co-ordinations are not achievable among the administrative subunits or responsibility centers. In that case, the individual managers are directly held responsible for their actions. Generally, attaining organizational objectives requires a proper functioning structure within the establishment. Hanini [24] that competent and skilled managers are to delegate authorities and responsibilities based on the structure and size 
of such establishment. Abebe and Abera [1]; Abo and Mohammed [2] opined that profitability as a reflection of productivity is a good measure and a tested indicator to ascertain the realization of the set objective of the organization.

Daloof [14] stated that from the global perspective, profitability objective is considered as one of the primary goals of any business venture. This is because without profitability objective being met, organizations especially in a structured and decentralized system, cannot survive. Thus, the going concern is no more guaranteed. Hence, measuring the current and past profitability performance objective and also projecting future profitability is very critical to the company's continuous existence. Profitability has been given considerable importance in finance and accounting literature. Hifza [26]; Abebe and Abera [1] said profitability is one of the most important objectives of financial management. Since one goal of financial management is to maximize the owners' wealth, then profitability is a very important determinant of performance. Bygrave, Hay and Reynolds [11] explained that profitability has the ability to provide a clear picture and guiding road map of the financial expectations of business actions and operational activities before they are executed Bygrave, Hay and Reynolds [11] opined that profitability, as one of the control measures has the motivating behavioral implications on managers and their subordinates such that specific goals are imposed, where there are measurements for systems, the delegation of duties, goal orientation, participation, pressure, and financial performance. Furthermore, more rewards for attaining goals are few and punishments are readily available for failures.

Karasioghu and Gokturk [29] opined that responsibility accounting has generated lots of unresolved debate in literature as to how it affects profitability or corporate performance. Responsibility accounting implies a management control system established on the principles of delegating and locating responsibility at the divisional levels, yet performance or profitability in some companies still suffers some setbacks. In other words, responsibility accounting is an organizational structure under which managers and those saddled with responsibilities are empowered and authorized by the organization to take decisions and responsibility for each activity that ensues within a specific job function of the organization. This means that under this arrangement, managers are held responsible for the actions of segments otherwise called the divisions, or departments, or branches. But the question, in spite of the various applications of responsibility accounting is, has profitability increased or improved in Nigeria? This is one of the problems this study seeks to find out at the end of the investigation". Owino [43] said responsibility accounting involves assessing controllable and uncontrollable costs or revenues traceable to individual managers. Owino [43] argued that however, in real life, tracing and determining these costs and revenues are dynamic and complex, but wellstructured responsibility accounting system is important Owino [43] argued that to reduce the problem of managing the large companies, responsibility accounting is one of the best tools of cost management used in the case of decentralization or divisionalization of activities. Performance measurement is considered as a management control system because economic planning and effective control and decision-making require that each unit's function is evaluated. Ideally, every business establishment is made up of people and resources to accomplish a certain economic goal, so, it is the firms planning that determines how the elements work together to achieve the overall goal of the firm". Mojgan [35] stated that the lines of authority should be fully defined before the responsibility system is implemented. When the powers and responsibilities are clearly determined and defined, there will appear a level of management structure and each will enjoy a sphere of responsibility within which individuals can make their own decision.

Chartered Institute of Management Accountant CIMA [12] defined responsibility accounting as a system of accounting that segregates revenue and costs into areas of personal responsibility in order to assess the performance attained by persons to whom authority has been assigned. Responsibility accounting can also be referred to as activity accounting, especially in a decentralized operational setup. It is used to measure, evaluate and monitor the decentralization process of organizations. Responsibility accounting aims to provide some accounting reports. This enables every manager to be aware of all the items, which are within his area of delegation and authority. CIMA [12] stated further that as a system of accounting, it distinguishes between controllable and uncontrollable cost. Gray [22] stated that with Responsibility accounting, it is possible to identify or recognize decision centers within an organization for the purpose of tracing costs to the individual managers who are charged with the responsibility of making decisions about costs and revenue in an organization. Consequently, this study investigated the effect of responsibility accounting (Independent Variable) on Profitability (Dependent variable) of the listed companies in Nigeria. The study expected that the dependent variable and its proxies would be positively affected by the explanatory variables of the cost of sales (COS), and operating (OPC).

\subsection{Statement of the Problem}

Kishore and Ghosh [31] stated that companies face difficulties in meeting their profitability goal because the managers' performance is not evaluated. If the performances of managers are not evaluated, it will be hard to determine when the profitability expectation is achieved, which is part of the essences of responsibility accounting. The study of Derbali and Jamel [13] posited that business failure is a common factor if proper functioning and evaluation are not properly handled among the organizational subunits or responsibility centers where the individual managers are directly held responsible for their actions. Commenting on profitability Adegbie, Olusanjo and Olaoye, [3]; Zimmerman [57] opined that the evidence of efficient responsibility accounting is measurable by the level of profit being generated. Makori and Jagongo [34]; Owolabi and Obida 
[44]; Padachi [45] argued that Profitability is the critical essence of business, according to. This is reflected in the dwindling profit of the organizations, as an indicator of profitability performance, showing the managers inability to create wealth for the owners and meeting the expectation of equity investors. Although, managers could be held responsible for the responsibilities under their control, however, the managers do not have direct control over uncontrollable costs and over the shareholders' wealth. Yet, their action influences the drivers of the shareholders' wealth creation. Consequently, there is a need to identify measures of performance that are related to shareholders, like Net Profit before Tax (NPBT). Bad performance of managers (and their subordinates) of the listed companies may have contributed to the inability of the firms to optimize the resources towards making profit for the shareholders, corporate objective attainment and ensuring that profitability objective is achieved. Furthermore, Ocansey and Enahoro [42] that the issue of controllability principle in responsibility accounting is controversial and continues to be the subject of scholarly debate in accounting and control literature.

Deloof [14]; Diamond [15] opined that the debate on the relationship between responsibility accounting and profitability in literature is ongoing. While findings from some studies claim that responsibility accounting is negatively related with profitability, others stress that it is positively related. Padachi [45] revealed that responsibility accounting had a positive relationship with profitability, while Friebel and Raith [20] showed a negative relationship. Friebel and Raith [20] stated that one of the problems facing organizations in Nigeria and elsewhere is the issue of scarcity of resources. As such, appropriate utilization and allocation of resources and delegation of duties in a decentralized organization, could lead to maximizing the resources and at the same time minimize the cost of production, which means production efficiency will ultimately be maximized and also profitability objective will be attained and the core values of the company and that of other stakeholders would be maintained through profitability.

The application of responsibility accounting cannot only strengthen internal control but also improve the production efficiency of enterprises. The correct application of responsibility accounting provides good performance and thereafter affects profitability. Previous studies in Nigeria provided evidence of lack of clarity of the degree of implementation of accounting responsibility to increase the operational efficiency and development of performance.

Consequently, this study investigated managers and other employee's performance in terms of responsibility accounting in the delegation, economic planning, and responsibility centers resource utilization, employing responsibility accounting proxies of (cost of sales, operating costs, and revenue) as they relate to profitability. For control purposes, responsibility centers are generally categorized into cost centers, investment centers, and revenues centers. This study measured individual managers managing the responsibility accounting centers of Cost centers with (Cost of sales of the
center-COS), the investment center with (Operating costsOPC) and revenue center. Therefore, the researcher investigated the impact of responsibility accounting on profitability in the listed companies on the floor of the Nigerian Stock Exchange for the period selected.

\subsection{Objective of the Study}

The objective of this study was to examine the effect of responsibility accounting on profitability in listed companies in Nigeria.

The specific objectives of the study were to:

1. Ascertain the effect of responsibility accounting on net profit before tax in listed companies Nigeria;

2. Assess the effect of responsibility accounting on earnings per share in listed companies in Nigeria

3. Determine the effect of responsibility accounting on return on assets in listed companies in Nigeria;

4. Evaluate the controlling effect of firm size on effect of responsibility accounting on net profit before tax, on earnings per share and on return on assets in listed companies in Nigeria.

\subsection{Hypotheses of the Study}

The following hypotheses stated in null form were tested in this study:

$\mathrm{H}_{0} 1$ : Responsibility accounting has no significant effect on net profit before tax of listed companies in Nigeria.

$\mathrm{H}_{0} 2$ : Responsibility accounting has no significant effect on earnings per share of listed companies in Nigeria.

$\mathrm{H}_{0} 3$ : Responsibility accounting has no significant effect on return on assets of listed companies in Nigeria.

$\mathrm{H}_{0} 4$ : Firm size does not have controlling effect on the effect of responsibility accounting on net profit before tax, on earnings per share and on return on assets of listed companies in Nigeria

\section{Literature Review}

\subsection{Conceptual Review.}

\subsubsection{Responsibility Accounting}

The concept of responsibility accounting is considered as an accounting system that collects, summarizes, and reports accounting data relating to the responsibility of managers. It provides information to evaluate each manager on revenue and expenditure over which that manager has control and authority, such that line of responsibilities could be fully defined. Responsibility accounting considers the ability to separate clearly the controllable and uncontrollable items.

Responsibility accounting has been defined in various ways. Abo and Mohamad [2]; Owino [43] defined responsibility accounting as an accounting method that gathers and prepares periodic reports about the information regarding the costs and/or the revenues of every position of responsibility in an organization to enable managers to plan and control the performance of these positions of responsibility. Similarly Zimmerman [57] stated that the 
responsibility accounting system is part of the performance evaluation system used to measure the operating results of a responsibility center. Therefore, responsibility accounting dictates that the performance measurement system measures the performance that results from the decision rights assigned to the responsibility center.

Magablih [33] stated that responsibility accounting then dictates that the performance measurement system measures the performance that results from the decision rights assigned to the responsibility center. Being held responsible for financial performance does not mean that the manager is penalized if actual results do not measure up to the budget goals. However, the manager should take the initiative to correct any unfavorable discrepancies, should understand the source of significant favorable or unfavorable discrepancies and should be prepared to explain the reasons for discrepancies to higher management.. An effective responsibility accounting is a system that measures the plans, budget, actions and actual results of each responsibility center Horngren [27] was of the opinion that a responsibility center can be structured to promote better alignment of individual and company goals.

Similarly Fowzia [19]; Yang Modell [53] stated that responsibility accounting is a management control system designed to make various responsibility managers accountable based on the principles of delegation and the location of their responsibility. Authority and responsibility is based on responsibility centers. Fowzia [19]; Yang and Modell [53]. Further stated that as a way of controlling operations in an organization, someone must be held responsible for each cost or else no one will be responsible and the cost will inevitably grow out of control Horngren, [27] furthermore stated that responsibility accounting or profitability accounting or activity accounting (which means the same thing) is a system that recognizes various decisions or responsibility centers throughout the organization and traces costs (and revenue, assets and liabilities) to the individual managers who are primarily responsible for making decisions about the costs, revenue, assets and liabilities in question. More so, responsibility accounting is a method of accumulating and reporting both budgeted and actual costs, by divisional managers responsible for them. On this system, business activities are identified with managers rather than products in order to make for effective control.

\subsubsection{Proxies of Responsibility Accounting}

\section{(i). Cost of Sales}

Cost of sales as one of the measures of responsibility accounting is the cost of making the products sold in a period. The expenses included in 'cost of sales' differs according to the activities or type of industry in which the entity operates. In a retailing business, the cost of sales might be just the purchase cost of the goods that have been sold while in a manufacturing business, the cost of sales might be the cost of producing the goods sold during the period, including raw materials, components, labor and other expenses incurred in production. Nibedita [39] opined that sometimes the cost of manufactured goods transferred to cost of sales is adjusted to reflect profit or loss arising from the manufacturer. The profit (or loss) on manufacture is ascertained on the basis of opportunity cost principle, i.e. is by reference to what the company would have paid for identical goods if it were purchased instead of manufacturing them. If such imputed total purchase value exceeds the cost of manufacture then a gross profit on manufacture would result. A loss of manufacture will occur if the cost of manufacture exceeds the imputed purchase value.

Cost Centre or Expense Centre: Derbali and Jamel [13] averred the cost of sales is used in this study to measure cost centers or expense centers. In measuring responsibility accounting, an expense center is a responsibility center in which inputs, but not outputs, are measured in monetary terms. Responsibility accounting is based on financial information relating to inputs (costs) and outputs (revenues). In an expense center of responsibility, the accounting system records only the cost incurred by the center, but the revenues earned (outputs) are excluded. An expense center measures financial performance in terms of cost incurred by it. In other words, the performance measured in an expense center is the efficiency of operation in that center in terms of the number of inputs used in producing some given output. The modus operandi is to compare actual inputs to some predetermined level that represents efficient utilization. The variance between the actual and budget standard would be indicative of the efficiency of the division.

Mojgan [35]; Adegbie, Olusanjo, and Olaoye [3] explained that in measuring the cost of sales as an absolute figure from the financials of the companies and the study of. Following these studies, the researchers measures Cost of sales $=\log$ of the cost of sales of the companies forming the units of sampling of the study.

\section{(ii). Operational Costs}

Direct Costs: Akeju [4]. Explain that these are costs that vary directly with the level of production. That is, they are costs that can be traced to having been incurred in manufacturing an item. They are also referred to as prime cost. Furthermore, Akeju [4] opined that direct cost could be direct labour cost, comprising wages paid to the workers that are wholly and exclusively working in the production line of the manufacturing companies or direct expenses which are other costs that are directly related to the production process.

Indirect Costs: These are costs that cannot be easily traced to the item being manufactured i.e. they are costs which do not vary directly with the cost of production. They are also referred to as overheads.

Investment Centers: The study measures the investment center considering the operational cost involved in the investment centers. Ideally, a center in which assets employed are also measured besides the measurement of inputs and outputs is called an investment center. Inputs are accounted for in terms of costs, outputs are calculated on investment center. Inputs are accounted for in terms of costs, outputs are accounted for in terms of revenues and assets employed in terms of values. It is the broadest measurement, 
in the sense that the performance is measured not only in terms of profits but also in terms of assets employed to generate profits. An investment center differs from a profit center in that an investment center is evaluated on the basis of the rate of return earned on the assets invested in the segment while a profit center is evaluated on the basis of excess revenue over expenses for the period.

Mojgan [35] investigated the role of responsibility accounting in organizations. The study measures operating cost using the absolute figure of the listed firms sampled Adegbie, Olusanjo, and Olaoye [3]. Study intends to follow the literature and measures operating costs as used in the study of, as follows: OPC $=\log$ of the total cost (absolute figure) of the listed companies that would form the sampling unit of this study.

\subsubsection{Profitability}

Machdar [32] argued the concept of Profitability could be termed as the ability to make a profit from all the business activities of an organization, company, firm, or an enterprise. It reveals how efficiently the management can make a profit by using all the resources available in the market. Harward and Upto [25] postulated that profitability is the ability of a given investment to earn a return from its use, but that profitability is not synonymous to the term efficiency, rather profitability is an index of efficiency to guide management for greater performance. The study of Hifza [26] opined that profitability is one of the most important objectives of financial management since one goal of financial management is to maximize the owner's wealth and profitability is a very important determinant of performance. A business that is not profitable cannot survive. Conversely, a business that is highly profitable has the ability to reward its owners with a large return on their investment. Similarly, the study of Nedles, Powers, and Crosson [38] opined that profitability is the ability to earn a satisfactory income. They further asserted that as a goal, profitability competes with liquidity for managerial attention for the reason that liquidity assets, although important, are not the best profit producing resources. Cash, for example, means purchasing power but a satisfactory profit can be made only if purchasing power is used to buy profit-producing (and less liquid) assets, such as inventory and long-term assets.

\subsubsection{Net Profit Before Tax}

Net profit before tax in this study relates to the profit available for the company before tax liabilities. The essence of this variable is to ascertain profit available after considering all the direct costs, overheads, and other operating expenses and evaluate the level of competences and efficiency of managers in managing various investment centers based on the decentralization policy in companies implementing responsibility accounting. Zahoor, Huma, Bader, and Muhammad [43]; Zhai, and Wang [56] opined that net profit before tax as profitability performance indicator, should be clearly differentiated between the performance of the managers and that of the division. Nawaiseh, Zeidan, Falahat, and Otish [37]; Eliwa [17] measured Net profit before tax (NPBT) in their studies. This study adopts from their studies and intends to measure net profit before tax as NPBT $=\log$ of net profit before tax (absolute figure) from the financials of the companies to be used for this study.

\subsection{Theoretical Review}

This section of the study shows the theoretical assumptions and foundation used for the study.

\subsubsection{Agency Theory}

The concept of agency theory was postulated by Berle and Means [9] who argued that due to a continuous dilution of equity ownership of large corporations, ownership and control become more separated. Jensen [28] opined that this situation gives professional managers an opportunity to pursue their interests instead of that of shareholders. That the issue of agency theory revolves around the subject matter of agency problems and its possible solutions.

The responsibility of running and managing the company will be with the managers on behalf of the shareholders. In any business contract, there is the possibility that conflict may arise especially when the owner is different from the day to day running and management of the company. The conflict could come in various ways: Conflict of interests, payment terms disagreements, dividend policy issues and many more. The Agency theory posits that there is a relationship between the principal (shareholders) and the agent of the principal (company's managers). This suggests that the firm can be viewed as a nexus of contracts (loosely defined) between resources holders. Panda and Leepsa, [47]. stated that An agency relationship arises whenever one or more individuals, called principal, hired one or more other individuals, called agents, to perform some services and then delegate decisionmaking authority to the agents. This study investigates the effects of responsibility accounting on the profitability of the listed companies in Nigeria, relating to the investors in this case, as the principal and the managers other employees as the agents. The investors voluntarily gave power to the managers to manage the resources on behalf of the investors. The idea of agency theory in terms of interests, separation of ownership from control, different kinds of information asymmetry and moral hazards, managing of resources and ownership control and managerial function is, therefore, relevant and related this study.

\subsubsection{Profitability Theory}

Hifza [26] averred that profitability was said to have been developed and used by American Economist, Francis Walker in the year 1900. Profitability studies classify measures and assess the performance of the firm in terms of the profits it earns with regards to the shareholders' investment or capital employed in the business... further explained that most investors only invest in the returns and the profit that the investment yields, therefore profitability could be used as a measure of the success of an investment. Furthermore, profitability is the business' ability to create earnings in 
relation to its expenses and other related costs of the business incurred during the relevant period. Therefore, the ability of a company to continue to operate and be in business largely depends on its ability to generate profit and continue to exist. Profitability objective is termed as one of the greatest essence of business venture. This study expects that responsibility accounting affects profitability positively. It then suggests that profitability is a performance measure of responsibility accounting. Therefore this study is hanging on the fact that profitability is important and associated with this study.

\subsubsection{Economic Efficiency Theory}

Stilwell [51] stated that the Economic efficiency theory was one of the theories postulated by the noneconomic theorists. However, the theory was said to have been developed and brought into literature by. The theory states that companies should achieve their output at the lowest possible cost per unit produced. According to this theory, optimal production can be achieved by economics of scale. Zerbe [55]; Said [50] of both stated that therefore, in the short run, maximum operational efficiency is attained at the level of output at which all accessible economics of scale takes advantage of such efficiency. In the long run, lifting the capacity of an existing system can increase the optimal level of production efficiency. The underlying economic performance of a company is measured basically by the efficient utilization of the resources at its disposal in other to attain profitability objectives of the establishment. This theory is deemed relevant and important to this study because an economically efficient application of the resources of the managers reflects how responsibility accounting affects profitability $[55,50]$.

\subsubsection{Accountability Theory}

Diamond (1984); Dow and Gorton (1997) averred that some scholars in their research work find that a more liquid market leads to better monitoring of managers as in. Agency theory states the importance of accountability as required from the managers by shareholders. The shareholders expect proper accountability of stewardship of their investment entrusted in the hands of the managers. Therefore, this theory is very relevant to the study as accountability is important in the operations of the firm by the managers who are to be evaluated and held accountable based on the performance of their responsibility centers. The managers and their subordinates are accountable to the shareholders and other stakeholders based on the delegations of responsibilities, duties and various centers resources under their control. Therefore accountability theory is considered important and relevant to this study $[15,16]$.

\subsection{Empirical Review}

Gharaibeh [21] conducted a research investigating the extent of the application of accounting responsibility and its impact on profitability and operational efficiency in the Jordanian industrial corporations companies. The study employed descriptive statistics and regression analysis. The study found that the organizational structure of Jordanian industrial public shareholding companies was divided into responsibility centers with a high degree of application, but there was no relationship between centers and profitability ratios and proportions operational efficiency The authorized managers of responsibility centers with powers and the existence of incentives are linked to the results of responsibility centers and they linked to rates of profitability. The study recommended increasing the attention to divide the organizational structure to responsibility centers and identify the goals which needed to be achieved by each center. Kingsley, Endurance, Sunny, and Ozele, [30] studied responsibility accounting issues and the effect of transfer pricing policy on the Nigerian economy. The study made a detailed analysis on transfer pricing issues and found that several activities of handling, planning and controlling were engaged in multinational firms in Nigeria by reducing the burden of corporate tax where responsibility accounting tool is used for decentralization. Patel [48]. made an investigation on the application and implementation of responsibility accounting. The study concluded and found that responsibility accounting was used as a good control system and performance evaluation tool in large companies. The study also found that the process of responsibility accounting had two parts: Standard costing and budgeting. The size of the organization forms the basis of implementing responsibility accounting. Large scale companies have benefited by using responsibility accounting systems as compared to small scale companies where each departmental manager is held responsible for his divisional performance.

Furthermore, Alshomaly [8]. studied the relationship between performance and adoption of the responsibility accounting system in the Jordanian medical sector. The study applied descriptive statistics in analyzing the data obtained from the sampled companies in the Jordanian industrial sector. The study revealed that Jordanian medical companies in the medical sector, adopted responsibility accounting system in the evaluation of the performance of the managers. Gharaibeh [21] conducted a research investigating the extent of the application of accounting responsibility and its impact on profitability and operational efficiency in the Jordanian industrial corporations companies. The study employed descriptive statistics and regression analysis. The study found that the organizational structure of Jordanian industrial public shareholding companies was divided into responsibility centers with a high degree of application, but there was no relationship between centers and profitability ratios and proportions operational efficiency. The authorized managers of responsibility centers with powers and the existence of incentives are linked to the results of responsibility centers and they linked to rates of profitability. The study recommended increasing the attention to divide the organizational structure to responsibility centers and identify the goals which needed to be achieved by each center. AlNimer and Warrad [6] examined whether liquidity through quick ratio has any significant impact on Jordanian banks profitability through return on asset (ROA). The study used 
the 2005-2011 financial reports of 15 Jordanian banks listed at Amman Stock Exchange (ASE). The study revealed that there was a significant positive impact of the independent variable quick ratio on the dependent variable of return on asset (ROA). That means that return on assets (ROA) in Jordanian banks was significantly influenced by liquidity. Kingsley, Endurance, Sunny, and Ozele, [30] studied responsibility accounting issues and the effect of transfer pricing policy on the Nigerian economy. The study made a detailed analysis on transfer pricing issues and found that several activities of handling, planning and controlling were engaged in multinational firms in Nigeria by reducing the burden of corporate tax where responsibility accounting tool is used for decentralization. Owolabi, and Obida, [44] studied the relationship between liquidity management and corporate profitability using return on investment (ROI), return on equity (ROE) and return on assets (ROA) of selected manufacturing companies listed on the Nigerian Stock Exchange. The study found that liquidity management measured in terms of the company's credit policies, cash flow management, and cash conversion cycle has a significant impact on return on investment, (ROI), return on equity (ROE) and return on assets (ROA. From the economy of Siri Lanka. Niresh, and Velnampy [40] studied the effects of firm size on the profitability of quoted manufacturing firms. The study employed data obtained from 15 companies which were active in the Colombo Stock Exchange between the years 2008 to 2012 for the study. The study equally employed some identified proxy variables to measure firm profitability using return on assets (ROA) and net profit (NP) whereas Total assets and Total Sales was utilized as indicators of firm size. The study result revealed that there is no indicative relationship between firm size and profitability of listed manufacturing firms. Also that firm size has no profound impact on the profitability of the listed manufacturing firms in Sri Lanka. Rani and Rani [49] investigated the implementation of responsibility accounting in the Jordanian industrial companies listed on the Amman Stock Exchange. A survey research design method was adopted, using 245 structured questionnaires. Descriptive and inferential statistics were used to analyze the data with the help of the Statistical package for social sciences (SPSS). The study found that some of the elements of responsibility accounting system were available in the Jordanian industrial companies such as the existence of structural reporting and preparation of budgets for performance evaluation. The study also showed a lack of the right incentives system and did not find any statistical evidence of performance comparison evaluation with an actual and budgeted performance of the companies.

Akenbor and Nkem [5] conducted an investigation on responsibility accounting as a system of measuring the performance of different segments being evaluated. For attaining their goal, they developed research questions, formulated hypothesis and reviewed related literature. As a research instrument, they designed questionnaire. The population had a sample of 32 accountants in Rivers State from the manufacturing industry. Collected data were analyzed using percentages and were tested using Chi-square (x2) test. The study found no correlation with the variables; as such that responsibility accounting is not at all suitable for the segment performance on specific manufacturing firms. The researcher suggested that to handle some of the challenges facing responsibility accounting, adequate effort would be needed by organizational executives to streamline cost centers. The study suggested that effectiveness can be achieved by developing market capitalization of those companies, providing enough skilled manpower and ensuring current data collection about cost, profit and investment centers of the Nigerian companies. Makori and Jagongo [34]. conducted a study on whether environmental accounting effects accurate information in the financial statements regarding the estimated social cost occasioned by the production externalities on the environment and how much deliberate intervention cost had been incurred to bridge the gap between the marginal social cost and the marginal private cost by a firm. The study also aimed at establishing whether there is any significant relationship between environmental accounting and profitability of selected firms listed in India. The data for the study were collected from annual reports and accounts of 14 randomly selected quoted companies in the Bombay Stock Exchange in India. The data were analyzed using multiple regression models. The study found that there was a negative significant relationship between Environmental Accounting and Return on Capital Employed (ROCE) and Earnings per Share (EPS) and a significant positive relationship between Environmental Accounting and Net Profit Margin and Dividend per Share. Based on this it was recommended that government should give a tax credit to organizations.

\subsection{Justification for the Study}

Fakir, Islam and Miah [18]; Machdar [32]; Rani and Rani [49]; Pajrok [46] studies on responsibility accounting have been inconclusive and controversial and no consensus has been reached, especially the impact of responsibility accounting on profitability. While some authors have established positive relationships in their studies, others have established negative or no relationship using shareholders' wealth as a proxy for responsibility accounting and while liquidity, return on investment; earnings per share and assets replacement were used as a proxy for profitability. This dissertation considers a shift on the research results of other studies. Rani and Rani [49] established a positive relationship while Pajrok [46] established a negative relationship using a survey. However, while the above studies used survey research design, this study would be based on a different dimension. This study intended to employ profitability identified proxies of return on assets (ROA), earnings per share (EPS) and net profit before tax (NPBT) to examine how they could be impacted by responsibility accounting of the listed companies in Nigeria.

From the theoretical perspective, most theories seem not to have considered human behavioral assumptions and the 
structural mechanism paradigm shift of Agency theory like the study of Goel Mazzola, Phan, Pieper, and Zachary [23]. This consideration is lacking in most studies conducted in Nigeria, thereby creating a theoretical gap in the literature. In filling these gaps, this study contributes to the literature in agency theory based on the behavioral and attitudinal paradigm shift of performance theory towards curbing opportunistic behavioral tendencies of the managers in decentralized organizations. Eliwa, [17] noted that some basic assumption of human nature is that there exists an association between a human being, the environment and his behavior. These assumptions underpin the study concept of environmental peculiarities. Human beings and their behavior are the product of their environment.

Consequently, this paper is significant as it would afford the management of the listed companies in Nigeria, especially, those operating a decentralized sub-unit to institute and adopt responsibility accounting principles in order to increase profitability and productivity in their operations. In addition, management can use responsibility accounting as a control mechanism to provide relevant information on a constant basis. It will equally serve as a basis for motivating the managers and the employees of various divisions and by so doing, enhance their economic welfare.

\section{Methodology}

\subsection{Research Design}

This study empirically investigated the effect of responsibility accounting on profitability in the listed Nigerian companies. The study adopted ex-post facto research design, the choice of ex-post facto research design is premised on the ground that it examined the past event relationship between the dependent and independent variables. The population of this study consisted of all the 173 listed companies on the floor of the Nigeria Stock Exchange (NSE) as of 31 December 2017 as contained in the NSE Factbook, ten (10) companies are selected as the sample representatives of this study. Convenience sampling technique was used to select the sample representative for this study based on time and data availability. The relevant data needed for this study were from secondary data. The secondary data extracted contained information from the published annual reports and accounts of the companies sampled for this study. Relevant information required to proxy the research variables were extracted from the statements profit and loss, statement of financial position detailing assets and liabilities of companies, including a statement of changes in equity and statement of cash flow for the period covered by the study. To ensure the validity of this study, the paper is presented to experts and made notable corrections. Data extracted also was validated by same means. The study established the effect between responsibility accounting and profitability. The study therefore, examined a cause and effect relationship between responsibility accounting (independent variable) and profitability (the dependent variable). To accomplish this, both descriptive and inferential statistics were employed in the study. The data analysis was carried out in two stages, i.e. descriptive and inferential statistics. The descriptive statistics were used to analyze the data for characteristics such as mean, median and maximum, while the inferential statistics were used to test the stated hypotheses. The panel regression models were also estimated using Unobserved Effects Model (UEM), while Hausman test was carried out to indicate the best estimation between fixed effect model and random effect model followed by other needed post estimation test.

\subsection{Model Specification}

Three natures of variables are used in this study; the dependent variable, independent variable and the control variable. The dependent variable is profitability measured as net profit before tax (NPBT), earnings per share (EPS) and return on assets (ROA); the independent variable is responsibility accounting measured as cost of sales and operational cost while firm size is used as the control variable.

The operationalization of the variables is thus:

$$
\begin{gathered}
\mathrm{Y}=f(\mathrm{X}) \\
\mathrm{Y}=f(\mathrm{X}, \mathrm{Z})
\end{gathered}
$$

Where

$\mathrm{Y}=$ Dependent Variable $=$ Profitability

$\mathrm{X}=$ Independent Variable=Responsibility Accounting

$\mathrm{Z}=$ Control Variable $=$ Firm Size $(\mathrm{FS})$

$\mathrm{Y}=\mathrm{y}_{1}, \mathrm{y}_{2}, \mathrm{y}_{3}$.

$\mathrm{y}_{1}=$ Net Profit before Tax (NPBT)

$\mathrm{y}_{2}=$ Earnings per Share (EPS)

$\mathrm{y}_{3}=$ Return on Assets (ROA)

$\mathrm{X}=\mathrm{x}_{1}, \mathrm{x}_{2}$

$\mathrm{x}_{1}=$ Cost of Sales (COS)

$\mathrm{x}_{2}=$ Operating Cost (OPC)

$\mathrm{Z}=\mathrm{z}=$ Firm Size (FS)

Functional Relationship

$$
\begin{gathered}
\mathrm{y}_{1}=f\left(\mathrm{x}_{1}, \mathrm{x}_{2}\right) ; \mathrm{NPBT}=f(\mathrm{COS}, \mathrm{OPC}) \\
\mathrm{y}_{1}=f\left(\mathrm{x}_{1}, \mathrm{x}_{2}, \mathrm{z}\right) ; \mathrm{NPBT}=f(\mathrm{COS}, \mathrm{OPC}, \mathrm{FS}) \\
\mathrm{y}_{2}=f\left(\mathrm{x}_{1}, \mathrm{x}_{2}\right) ; \mathrm{EPS}=f(\mathrm{COS}, \mathrm{OPC}) \\
\mathrm{y}_{2}=f\left(\mathrm{x}_{1}, \mathrm{x}_{2}, \mathrm{z}\right) ; \mathrm{EPS}=f(\mathrm{COS}, \mathrm{OPC}, \mathrm{FS}) \\
\mathrm{y}_{3}=f\left(\mathrm{x}_{1}, \mathrm{x}_{2}\right) ; \mathrm{ROA}=f(\mathrm{COS}, \mathrm{OPC}) \\
\mathrm{y}_{3}=f\left(\mathrm{x}_{1}, \mathrm{x}_{2}, \mathrm{z}\right) ; \mathrm{ROA}=f(\mathrm{COS}, \mathrm{OPC}, \mathrm{FS})
\end{gathered}
$$

Models of the Study

Model (1)

$$
\mathrm{NPBT}_{\mathrm{it}}=\beta_{0}+\beta_{1} \mathrm{COS}_{\mathrm{it}}+\beta_{2} \mathrm{OPCit}+\varepsilon_{\mathrm{it}}
$$

Model (2)

$$
\mathrm{NPBT}_{\text {it }}=\beta_{0}+\beta_{1} \mathrm{COSit}+\beta_{2} \mathrm{OPCit}+\beta_{4} \mathrm{FS}_{\text {it }}+\varepsilon_{\text {it }}
$$

Model (3) 


$$
\mathrm{EPS}_{\mathrm{it}}=\beta_{0}+\beta_{1} \mathrm{COS}_{\mathrm{it}}+\beta_{2} \mathrm{OPC}_{\mathrm{it}}+\varepsilon_{\mathrm{it}}
$$

Model (4)

$$
\mathrm{EPS}_{\mathrm{it}}=\beta_{0}+\beta_{1} \mathrm{COS}_{\mathrm{it}}+\beta_{2} \mathrm{OPC}_{\mathrm{it}}+\beta_{4} \mathrm{FS}_{\mathrm{it}}+\varepsilon_{\mathrm{it}}
$$

Model (5)

$$
\mathrm{ROA}_{\mathrm{it}}=\beta_{0}+\beta_{1} \mathrm{COS}_{\mathrm{it}}+\beta_{2} \mathrm{OPC}_{\mathrm{it}}+\varepsilon_{\mathrm{it}}
$$

Model (6)

$$
\mathrm{ROA}_{\mathrm{it}}=\beta_{0}+\beta_{1} \mathrm{COS}_{\mathrm{it}}+\beta_{2} \mathrm{OPC}_{\mathrm{it}}+\beta_{4} \mathrm{FS}_{\mathrm{it}}+\varepsilon_{\mathrm{it}}
$$

Where

ROA=Return on Assets

EPS=Earnings per share

ROE= Return on equity

NPBT $=$ Net Profit before Tax

COS $=$ Cost of Sales

$\mathrm{OPC}=$ Operating Cost

FS=Firm Size

$\beta_{0}=$ the regression intercept which is constant

$\beta_{1}-\beta_{4}=$ the coefficient of the explanatory variable

$\varepsilon=$ the error term of the model

$i=$ number of firms

$t=$ years of observations

\section{Results and Discussion of Findings}

Both descriptive and inferential statistics were employed in the study. The data analysis was carried out in two stages, i.e. descriptive and inferential statistics. The descriptive statistics were used to analyze the data for characteristics such as mean, median and maximum, while the inferential statistics were used to test the stated hypotheses. The panel regression models were also estimated using Unobserved Effects Model (UEM), while Hausman test was carried out to indicate the best estimation between fixed effect model and random effect model followed by other needed post estimation test

\subsection{Pre-estimation Analysis}

The basic statistical features of the financial figures and ratios of the variables used in measuring the explanatory variable, explained variable as well as the control variable are explained in this section. Also, the multicolinearity analysis carried out, testing for the existence of unhealthy association among the explanatory variables, using multicolinearity matrix, were as well presented in this section.

Table 1 Characteristics of the Variables.

\begin{tabular}{lllll}
\hline Variables & Mean & Std. Dev. & Min. & Max. \\
\hline NPBT & 7578.63 & 19375.89 & -34032.28 & 94056.00 \\
EPS & 144.71 & 244.43 & -637.00 & 959.00 \\
ROA & 4.80 & 8.35 & -18.04 & 32.56 \\
COS & 43077.13 & 83062.65 & 365.75 & 438853.00 \\
OPC & 57921.98 & 112311.10 & 525.08 & 558883.00 \\
FS & 9.85 & 2.38 & 6.46 & 15.47 \\
\hline
\end{tabular}

Source: Researchers Work, 2019.

\section{Interpretation}

From table 1, the mean value of 4.8 for ROA is an indication that 4.8 per cent returns were generated on the average by the considered firms within the period of this study via the usage of the total assets; while the firms reported losses at some period leading to minimum return on asset of -18.04 per cent, and the maximum return generated from the use of total asset as reported from the output of the analysis revealed 32.56 per cent. The standard deviation of 8.35 implies that risk is associated in predicting the rate of return to be derived by firms from the use of total asset; therefore, it is risky predicting the outcome of return from the total asset base. Considering the standard deviation statistics of every other variables other than that of firm size (FS); the associated risk of prediction are very high especially that of net profit before tax, cost of sales and operating cost having standard deviations of 19375.89, 83062.65 and 112311.1. possibly the huge standard deviation of these three variables might be as a result of the units of measurements as they are used in absolute form in millions of naira. Firms considered in this study generated huge loss of 34,032.28 million within the period covered as well as highest earnings before tax of 94, 056 million, while on the average; the firms reported 7,578.63 million as net profit before tax. The cost of sales and the operating costs are highly volatile as the mean differs widely from the minimum and the maximum value. Averagely, the firms incurred 43,077.13 million and $57,921.98$ million as cost of sales and operating cost which was quite huge and requires attention for its reduction through cost reduction and control techniques.

\subsection{Multicolinearity Analysis}

Multicolinearity test was conducted using correlation matrix test and the result being presented $\mathrm{i}$

Table 2 Mulricollinearity Test.

\begin{tabular}{llll}
\hline Variable & COS & OPC & FS \\
\hline COS & 1.00 & & \\
OPC & 0.6838 & 1.00 & \\
FS & 0.7493 & 0.7841 & 1.00 \\
\hline
\end{tabular}

Source: Researchers Work (2019).

\section{Interpretation}

From table 2, the result of the correlation matrix having the least absolute value of 0.6838 and the highest of 0.7841 evidenced that the explanatory variables are not multicorrelated based on the proposition of Baltagi (2015) which asserted that correlation coefficient should not exceed the threshold limit of 0.75 for the independent variables to be able to work together in a model, thus no problem of multi colinearity among the measures of the explanatory variables.

\subsection{Inferential Statics}

Regression analysis was adopted to test the hypotheses

\subsubsection{Test of Hypotheses One}

Hypothesis One: 
Research Objective: To ascertain the effect of responsibility accounting on net profit before tax in listed companies in Nigeria.

Research Question: To what extent does responsibility accounting affect net profit before tax of listed companies in
Nigeria?

Research Hypothesis (Ho): Responsibility accounting has no significant effect on net profit before tax of listed companies in Nigeria.

Table 3 Test of Hypotheses One (without and with control variable).

\begin{tabular}{|c|c|c|c|c|c|c|c|c|}
\hline \multirow[b]{3}{*}{ Constant } & \multicolumn{4}{|c|}{ MODEL ONE (without control variable) } & \multicolumn{4}{|c|}{ MODEL TWO (with control variable) } \\
\hline & \multicolumn{4}{|c|}{ Pooled OLS regression with Cluster Errors } & \multicolumn{4}{|c|}{ Pooled OLS regression with Cluster Errors } \\
\hline & 2224.85 & 1204.33 & 1.85 & 0.068 & -18399.6 & 6394.46 & -2.88 & 0.005 \\
\hline Variable & Coeff & Std. Err & t-test & Prob & Coeff & Std. Err & t-test & Prob \\
\hline $\operatorname{COS}$ & -0.752 & 0.072 & -10.45 & 0.00 & -0.723 & 0.07 & -10.10 & 0.00 \\
\hline $\mathrm{OPC}$ & 0.652 & 0.053 & 12.25 & 0.00 & 0.581 & 0.055 & 10.51 & 0.00 \\
\hline FS & - & - & - & - & 2315.6 & 706.27 & 3.28 & 0.001 \\
\hline Hausman Test & \multicolumn{4}{|c|}{$\begin{array}{l}0.6964 ; \mathrm{F}_{(2,97)}=114.56(0.00) \\
\operatorname{chi}^{2}{ }_{(2)}=13.67(0.00)\end{array}$} & \multicolumn{4}{|c|}{$\begin{array}{l}0.7242 ; F_{(3,96)}=87.63(0.00) \\
\operatorname{chi}_{(1)}^{2}=0.30(0.585)\end{array}$} \\
\hline $\begin{array}{l}\text { Breusch and Pagan Lagrangian } \\
\text { multiplier test for random effects }\end{array}$ & & & & & \multicolumn{4}{|c|}{$\operatorname{chi}_{(1)}^{2}=0.00(1.00)$} \\
\hline Testparm Test & \multicolumn{4}{|c|}{$F_{(9,79)}=1.16(0.33)$} & & & & \\
\hline Heteroskedasticity Test & \multicolumn{4}{|c|}{$\operatorname{chi}_{(1)}^{2}=43.72(0.00)$} & \multicolumn{4}{|c|}{$\operatorname{chi}_{(1)}^{2}=69.80(0.00)$} \\
\hline Serial Auto-Correlation Test & \multicolumn{4}{|c|}{$F_{(1,9)}=13.44(0.01)$} & \multicolumn{4}{|c|}{$F_{(1,9)}=11.81(0.01)$} \\
\hline
\end{tabular}

Source: Researchers Work (2019).

Interpretation of the Statistical Tests' Results

Hausman Test: from the statistical figures presented in Table 3, the Hausman result for model One A showed that fixed effect is more appropriate for the estimation judging from its probability figure of 0.00 and based on its null hypothesis which states that there is presence of unsystematic difference in the model coefficients; therefore, the null hypothesis was rejected because no unsystematic difference in the model coefficients. However, the result of the Testparm which was conducted to confirm the authenticity of Hausman negates Hausman report with probability value greater than 5 per cent significance level (0.33), and thus favoured Pooled OLS as the most appropriate estimator among fixed effect, random effect and Pooled OLS. On the contrary, when Firm Size (FS) was introduced as control variable, the result of the Hausman changed to favoured Random Effect with probability value greater than 5 per cent significance level (0.585), while Breusch and Pagan Lagrangian multiplier test for random effects having probability value of 1.00 being greater than 5 per cent chosen significant level nullified the result of Hausman and thus supported Pooled OLS as the most appropriate estimator among fixed effect, random effect and Pooled Ordinary Least Square Regression analysis.

Diagnostic Tests

The Breusch-Pagan/Cook-Weisberg Test for heteroskedasticity for both models are significant $(\rho=0.00$; 0.00 ) indicating that the models are heteroskedastic, which imply that the residuals of the models are not static over time of the study; likewise, Wooldridge test for serial autocorrelation in both models are significant ( $\rho$-values of 0.01 and 0.01 ) revealing the presence of first order autocorrelation among the series in both models respectively.

In accordance with the results of the post-estimation tests carried out, both models are estimated using Pooled Ordinary Least Square Regression with cluster errors as depicted in table 3.

Model 1

$$
\begin{gathered}
\mathrm{NPBT}_{\mathrm{it}}=\beta_{0}+\beta_{1} \mathrm{COS}_{\mathrm{it}}+\beta_{2} \mathrm{OPC}_{\mathrm{it}}+\varepsilon_{\mathrm{it}} \\
\mathrm{NPBT}_{\mathrm{it}}=2224.85-0.752 \mathrm{COS}_{\mathrm{it}}+0.652 \mathrm{OPC}_{\mathrm{it}}+\varepsilon_{\mathrm{it}}
\end{gathered}
$$

Model 2

$$
\begin{gathered}
\mathrm{NPBT}_{\mathrm{it}}=\beta_{0}+\beta_{1} \mathrm{COS}_{\mathrm{it}}+\beta_{2} \mathrm{OPC}_{\mathrm{it}}+\beta_{3} \mathrm{FS}_{\mathrm{it}}+\varepsilon_{\mathrm{it}} \\
\mathrm{NPBT}_{\mathrm{it}}=-18400-0.723 \mathrm{COS}_{\mathrm{it}}+0.581 \mathrm{OPC}_{\mathrm{it}}+2315.6 \mathrm{FS}_{\mathrm{it}}+\varepsilon_{\mathrm{it}}
\end{gathered}
$$

Interpretation

From the regression model 1a specified, it was found that cost of sales (COS) and operational cost (OPC) significantly affect net profit before tax (NBPT) of the listed companies in Nigeria; while COS negatively influence NPBT, OPC exerted positive effect. The coefficients of the cost of sales evidenced that as cost of sales increases by N1m, NPBT would decline by 0.752 million. On the contrary, as operational cost increases by 0.652 million, judging from the result of the combined effect of the independent variable on the dependent variable, the probability of the F-statistics with $\rho=0.00$ less than 0.05 level of significance adopted for this study revealed that responsibility accounting measured as cost of sales and operational cost significantly affect profitability measured as net profit before tax (NPBT); the adjusted R-squared of 0.696 is an indication that the joint variation in the independent variable would lead to 69.6 per cent changes in NPBT of listed companies in Nigeria. Therefore, this study rejects the null hypothesis one which states that responsibility accounting has no significant effect on net profit before tax (NPBT) while the study accepted the alternate hypothesis that responsibility accounting has significant effect on net profit before tax (NPBT) of listed companies in Nigeria.

With Control Variable: 
With the introduction of firm size (FS) as control variable to model $1 \mathrm{a}$ to form model $1 \mathrm{~b}$, it was noticed that cost of sales (COS), operational cost (OPC) and firm size (FS) significantly affect net profit before tax (NBPT) of the listed companies in Nigeria; while COS negatively influence NPBT, FS and OPC exerted positive effect with an increase of 0.581 million. The coefficients of the cost of sales evidenced that as cost of sales increases by N1m, NPBT would decline by 0.723 million. On the contrary, as operational cost increases by Judging from the result of the combined effect of the independent variable on the dependent variable, the probability of the F-statistics with $\rho=0.00$ less than 0.05 level significance revealed that responsibility accounting measured as cost of sales and operational cost significantly affect profitability measured as net profit before tax (NPBT); the adjusted R-squared of 0.696 is an indication that the joint variation in the independent variable would lead to 69.6 per cent changes in NPBT of listed companies in Nigeria. Therefore, this study rejects the null hypothesis One which states that responsibility accounting has no significant effect on net profit before tax (NPBT) while the study accepted the alternate hypothesis that responsibility accounting has significant effect on net profit before tax (NPBT) of listed companies in Nigeria.

Discussion of Findings

Interpreting the regression coefficients, the results clearly shows that in the model without control variable; the coefficient [coefficient $=0.652 ; p$-value $=0.000$ ] of Operating Cost (OPC) is positive and statistically significant at $5 \%$ level. The coefficient [coefficient $=0.581 ; p$-value $=0.000$ ] is positive and statistically significant at $1 \%$ level with the inclusion of control variables. This result aligns with the study of [11] and that of [6], who had similar results in their studies and asserted that operating cost positively and significantly affect net profit before tax of listed companies. Noticeably, the coefficient [coefficient $=-0.752$; $p$-value $=0.00$ ] of cost of sales (COS) is negative and highly statistically significant in the models without control variables. The study result as reported is in consistent with the study of [34]. The coefficient [coefficient $=-0.723 ; p$-value $=0.000$ ] is still negative and significant with the inclusion of control variables. Generally, the findings of this study is similar to that of $[48,31]$ who concluded that responsibility accounting significant influence net profit before tax of listed companies; and found that responsibility accounting was used as a good control system and performance evaluation tool in large companies.

\subsubsection{Test of Hypothesis Two}

Research Objective: assess the effect of responsibility accounting on earnings per share in listed companies in Nigeria

Research Question: To what extent does responsibility accounting affect the earnings per share of listed companies in Nigeria?

Research Hypothesis (Ho): Responsibility accounting does not significantly influence earnings per share of listed companies in Nigeria.

Table 4. Test of Hypotheses Two (without and with control variable).

\begin{tabular}{|c|c|c|c|c|c|c|c|c|}
\hline \multirow[b]{3}{*}{ Constant } & \multicolumn{4}{|c|}{ MODEL THREE (without control variable) } & \multicolumn{4}{|c|}{ MODEL FOUR (with control variable) } \\
\hline & \multicolumn{4}{|c|}{ Pooled OLS regression with Cluster Errors } & \multicolumn{4}{|c|}{ Pooled OLS regression with Cluster Errors } \\
\hline & 133.24 & 27.73 & 4.81 & 0.00 & -18399.6 & 6394.46 & -2.88 & 0.005 \\
\hline Variable & Coeff & Std. Err & t-test & Prob & Coeff & Std. Err & t-test & Prob \\
\hline $\cos$ & 0.001 & 0.002 & 0.42 & 0.673 & 0.002 & 0.002 & 1.30 & 0.195 \\
\hline OPC & -0.0003 & 0.001 & -0.26 & 0.792 & -0.002 & 0.001 & -1.97 & 0.052 \\
\hline FS & - & - & - & - & 67.72 & 15.69 & 4.32 & 0.00 \\
\hline Adj. R²; F-Stat (Prob) & \multirow{2}{*}{\multicolumn{4}{|c|}{$\begin{array}{l}-0.0112 ; \mathrm{F}_{(2,97)}=0.45(0.64) \\
\operatorname{chi}^{2}{ }_{(2)}=8.83(0.01)\end{array}$}} & \multirow{2}{*}{\multicolumn{4}{|c|}{$\begin{array}{l}0.1442 ; \mathrm{F}_{(3,96)}=6.56(0.00) \\
\mathrm{chi}^{2}{ }_{(1)}=0.17(0.6833)\end{array}$}} \\
\hline Hausman Test & & & & & & & & \\
\hline $\begin{array}{l}\text { Breusch and Pagan Lagrangian } \\
\text { multiplier test for random effects }\end{array}$ & & & & & \multicolumn{4}{|c|}{$\operatorname{chi}_{(1)}^{2}=14.67(0.00)$} \\
\hline Testparm Test & \multicolumn{4}{|c|}{$\mathrm{F}_{(9,79)}=0.43(0.92)$} & & & & \\
\hline Heteroskedasticity Test & $\operatorname{chi}_{(1)}^{2}=2$ & $.00)$ & & & \multicolumn{4}{|c|}{$\operatorname{chi}_{(1)}^{2}=30.77(0.00)$} \\
\hline Serial Auto-Correlation Test & \multirow{2}{*}{\multicolumn{4}{|c|}{$F_{(1,9)}=215.99(0.00)$}} & \multicolumn{4}{|c|}{$F_{(1,9)}=202.15(0.00)$} \\
\hline Cross-sectional Dependence & & & & & $-0.657(0$. & & & \\
\hline
\end{tabular}

Source: Researchers Work (2019).

\section{Interpretation of the Statistical Tests' Results}

Hausman Test: the result of this test for model 2A evidenced that fixed effect is more appropriate for the estimation considering the $\rho$-value of 0.00 which implies that there is no unsystematic difference in the model coefficients. contrarily, Testparm test was conducted to confirm the authenticity of Hausman, the result negates Hausman report with $\rho$-value of 0.92 which is greater than $5 \%$ chosen level of significance and thus the result favoured Pooled OLS as the most appropriate estimator among fixed effect, random effect and Pooled OLS.

When Firm Size (FS) was introduced as control variable, the result of the Hausman became insignificant and thus favoured Random Effect with $\rho$-value of 0.6833 which is greater than 5 per cent significance level $(0.585)$, it is an indication that there exist unsystematic difference in the model coefficients. Breusch and Pagan Lagrangian multiplier test for random effects conducted to confirm the result of the Hausman test reported probability value of 0.00 . This aligned with the result of the Hausman test and therefore Random 
Effect is adjudged the most appropriate estimator among

Fixed Effect, Random Effect and Pooled OLS.

Diagnostic Tests

The Breusch-Pagan/Cook-Weisberg Test for heteroskedasticity for both models are significant $(\rho=0.00$; 0.00) indicating that the models have heteroskedasticity problem, which imply that the residuals of the models are not constant over time of the study. The result of the Wooldridge test carried out to determine the issue of serial autocorrelation in both models are significant ( $\rho$-values of 0.00 and 0.00 ) revealing the residuals and the coefficients are correlated in both models respectively. The Cross-sectional dependence test carried out in Model $2 \mathrm{~b}$ having insignificant probability value of 0.51 showed that there is no cross sectional dependence problem in the model.

With the results of the post-estimation tests carried out, both models are estimated using Pooled Ordinary Least Square Regression with cluster errors as depicted in table 4

Model 3

$$
\begin{gathered}
\mathrm{EPS}_{\mathrm{it}}=\beta_{0}+\beta_{1} \mathrm{COS}_{\mathrm{it}}+\beta_{2} \mathrm{OPC}_{\mathrm{it}}+\varepsilon_{\mathrm{it}} \\
\mathrm{EPS}_{\mathrm{it}}=133.24+0.001 \mathrm{COS}_{\mathrm{it}}-0.0003 \mathrm{OPC}_{\mathrm{it}}+\varepsilon_{\mathrm{it}}
\end{gathered}
$$

Model 4

$$
\begin{gathered}
\mathrm{EPS}_{\mathrm{it}}=\beta_{0}+\beta_{1} \mathrm{COS}_{\mathrm{it}}+\beta_{2} \mathrm{OPC}_{\mathrm{it}}+\beta_{3} \mathrm{FS}_{\mathrm{it}}+\varepsilon_{\mathrm{it}} \\
\mathrm{EPS}_{\mathrm{it}}=-18399.6+0.002 \mathrm{COS}_{\mathrm{it}}-0.002 \mathrm{OPC}_{\mathrm{it}}+67.72 \mathrm{FS}_{\mathrm{it}}+\varepsilon_{\mathrm{it}}
\end{gathered}
$$

\section{Interpretation}

As depicted in the Model three of table 4, it was discovered that cost of sales (COS) and operational cost (OPC) insignificantly affect earnings per share (EPS) of the listed companies in Nigeria. Cost of Sales (COS) has positive effect on earnings per share with a co-efficient of 0.001 which shows that $1 \%$ increase in cost of sales will increase earnings by $0.1 \%$. the operating cost has negative coefficient of 0.0003 on earnings per share. The Adjusted $R^{2}$ of -0.0112 is an indication that the contribution of responsibility accounting on earning per share is not present. The Fstatistics of 0.45 and the P-Value of 0.64 is an indication that without the control variable, there is no significant effect of responsibility accounting on earning per share. Hence the null hypothesis was not rejected. With the introduction of control variable of size, the cost of sales has positive effect with earnings per share with a coefficient of 0.002 million while operating cost with a negative coefficient with negative coefficient of 0.002 shows that $1 \%$ increase in operating cost will reduce earnings per share by 0.002 million naira the coefficient of size is 67.72 positive which shows that's $1 \%$ increase in size will result to 67.72 million increase in EPS, then the $\mathrm{R}^{2}$ is 0.1442 which shows that responsibility accounting is $14.42 \%$ in earning per share composition while the remaining 85.58 is explained by variables outside the model, probability of the F-statistics with $\rho=0.6392$ indicated that responsibility accounting measured as cost of sales and operational cost insignificantly affect profitability measured as earnings per share (EPS).

\section{Decision}

Based on the insignificant result of the F-statistics with $\rho$ value of 0.6392 which is greater than $5 \%$ significance level; this study accepts the null hypothesis Three which states that responsibility accounting has no significant effect on earnings per share (EPS) and rejects the alternate hypothesis that responsibility accounting has significant effect on earnings per share (EPS) of listed companies in Nigeria.

With Control Variable:

With the inclusion of firm size (FS) as control variable in model 4 , it was observed that at $5 \%$ chosen significant level, cost of sales (COS) and operational cost (OPC) insignificantly affect earnings per share (EPS) while firm size (FS) significantly affect EPS of the listed companies in Nigeria. This implies that as the size of firm changes by a unit, EPS of listed Nigerian companies increases by 67.72 kobo. The probability of the F-statistics with $\rho=0.00$ measuring the combined effect of cost of sales (COS), operational cost (OPC) and firm size (FS) revealed that responsibility accounting measured as cost of sales and operational cost controlling for firm size significantly affect earnings per share (EPS) of Nigerian listed companies; the adjusted R-squared of 0.1442 is an indication that the joint variation in the independent variable and control variable (FS) would result to 14.42 per cent changes in EPS of listed companies in Nigeria.

Decision

In accordance with the result of the F-statistics with $\rho=0.00$, this study rejects the null hypothesis Three which states that firm size does not significantly control the relationship between responsibility accounting and earnings per share (EPS) of listed companies in Nigeria while the study accepted the alternate hypothesis which implies that firm size significantly controlled the relationship between responsibility accounting and earnings per share (EPS) of listed companies in Nigeria.

Discussion of Findings

The insignificant result obtained is consistent with the study of Mojgan (2012). [35], but negates the findings of Alshomaly (2013). [8]. possibly due to the differences in the economies of two nations were the studies were conducted. Overall, the results suggest the acceptance of the null hypothesis, which states that there is no significant effect of responsibility accounting on earnings per share in listed companies in Nigeria. Although, when Firm size (FS) was introduced as control variable, the impact of the relationship changes, and made the result aligned with the findings Adegbie, Olusanjo, and Olaoye (2018); Owolabi, and Obida (2012). [3, 44] who found that responsibility accounting variables have significant impact on earnings per share of companies quoted on Nigerian Stock Exchange. It can be deduced that larger firms have tendency of managing their cost of sales and operational cost effectively thus significantly impacting on their earnings per share.

\subsubsection{Test of Hypothesis Three}

Research Objective: determine the effect of responsibility 
accounting on return on assets in listed companies in Nigeria

Research Question: How does responsibility accounting affect return on assets of listed companies in Nigeria?
Research Hypothesis (Ho): Responsibility accounting has no significant effect on return of assets of the listed companies in Nigeria.

Table 5. Test of Hypotheses Three (without and with control variable).

\begin{tabular}{|c|c|c|c|c|c|c|c|c|}
\hline \multirow[b]{3}{*}{ Constant } & \multicolumn{4}{|c|}{ MODEL FIVE (without control variable) } & \multicolumn{4}{|c|}{ MODEL SIX (with control variable) } \\
\hline & \multicolumn{4}{|c|}{$\begin{array}{l}\text { Random EffectGeneralized Least Square regression } \\
\text { with Robust Errors }\end{array}$} & \multicolumn{4}{|c|}{ Random EffectGeneralized Least Square regression } \\
\hline & 5.247 & 2.175 & 2.41 & 0.016 & 3.005 & 7.64 & 0.39 & 0.694 \\
\hline Variable & Coeff & Std. Err & t-test & Prob & Coeff & Std. Err & t-test & Prob \\
\hline COS & -0.00001 & 0.00 & -1.15 & 0.251 & -0.000 & 0.000 & -0.16 & 0.874 \\
\hline $\mathrm{OPC}$ & 0.000 & 0.000 & 0.51 & 0.61 & -0.000 & 0.000 & -0.05 & 0.957 \\
\hline FS & - & - & - & - & 0.239 & 0.788 & 0.30 & 0.761 \\
\hline Hausman Test & \multicolumn{4}{|c|}{$\operatorname{chi}_{(2)}^{2}=0.09(0.9552)$} & \multicolumn{4}{|c|}{$\operatorname{chi}_{(1)}^{2}=1.37(0.2415)$} \\
\hline $\begin{array}{l}\text { Breusch and Pagan Lagrangian } \\
\text { multiplier test for random effects }\end{array}$ & \multicolumn{4}{|c|}{$\operatorname{chi}_{(1)}^{2}=85.62(0.00)$} & \multicolumn{4}{|c|}{$\operatorname{chi}_{(1)}^{2}=56.19(0.00)$} \\
\hline Heteroskedasticity Test & \multicolumn{4}{|c|}{$\operatorname{chi}^{2}{ }_{(1)}=5.92(0.0149)$} & \multicolumn{4}{|c|}{$\operatorname{chi}_{(1)}^{2}=1.77(0.1835)$} \\
\hline Serial Auto-Correlation Test & \multicolumn{4}{|c|}{$F_{(1,9)}=3.5(0.0941)$} & \multicolumn{4}{|c|}{$F_{(1,9)}=3.543(0.0925)$} \\
\hline Cross-sectional Dependence Test & \multicolumn{4}{|c|}{$-0.786(0.4318)$} & \multicolumn{4}{|c|}{$-0.691(0.4893)$} \\
\hline
\end{tabular}

Source: Researchers Work (2019)

Interpretation of the Statistical Tests' Results

From table 5 Hausman Test: the results of this test for both model five and six with $\rho$-values of 0.9552 and 0.2415 which is greater than $5 \%$ chosen level of significance supported the appropriateness of random effect GLS regression. Also, the results of the Breusch and Pagan Lagrangian multiplier test for random effect with $\rho$-values of 0.00 and 0.00 for both Models which is less than $5 \%$ chosen level of significance was consistent with the outcome of the Hausman test; which implies that there is unsystematic difference in the models' coefficients. Therefore, Random Effect Generalized Least Square regression analysis is adjudged the most appropriate estimator among fixed effect, random effect and Pooled OLS in estimating both Models Three A and B.

Diagnostic Tests

The result of The Breusch-Pagan/Cook-Weisberg Test for heteroskedasticity for Model three A reflected that the model is heteroskedastic $(\rho=0.00)$ indicating that the model Three A has heteroskedasticity problem, which imply that the residuals of the models are not constant over time of the study. On the contrary, with the inclusion if Firm Size (FS) as control variable; the model did not exhibit the presence of heteroskedasticity problem with $\rho$-value of 0.1835 which is greater than the expected significance level. The result of the Wooldridge test carried out to determine the issue of serial auto-correlation in both models is significant ( $\rho$-values of 0.0941 and 0.0925 ) proved that the residuals and the coefficients are correlated in both models respectively. The Cross sectional dependence test carried out on Model 3a and $3 \mathrm{~b}$ having insignificant probability values of 0.4318 and 0.4893 showed that there is no cross sectional dependence problem in the models.

With the results of the post-estimation tests carried out, model 5 was estimated using Random Effect Generalized Least Square regression with Robust Errors while model 6 was estimated using Random Effect Generalized Least Square regression method as depicted in table 5.
Model 5

$$
\begin{gathered}
\mathrm{ROA}_{\mathrm{it}}=\beta_{0}+\beta_{1} \mathrm{COS}_{\mathrm{it}}+\beta_{2} \mathrm{OPC}_{\mathrm{it}}+\varepsilon_{\mathrm{it}} \\
\mathrm{ROA}_{\mathrm{it}}=5.247-0.001 \mathrm{COS}_{\mathrm{it}}+0.0001 \mathrm{OPC}_{\mathrm{it}}+\varepsilon_{\mathrm{it}}
\end{gathered}
$$

Model 6

$$
\begin{gathered}
\mathrm{ROA}_{\mathrm{it}}=\beta_{0}+\beta_{1} \mathrm{COS}_{\mathrm{it}}+\beta_{2} \mathrm{OPC}_{\mathrm{it}}+\beta_{3} \mathrm{FS}_{\mathrm{it}}+\varepsilon_{\mathrm{it}} \\
\mathrm{ROA}_{\mathrm{it}}=3.005-0.000 \mathrm{COS}_{\mathrm{it}}-0.000 \mathrm{OPC}_{\mathrm{it}}+0.239 \mathrm{FS}_{\mathrm{it}}+\varepsilon_{\mathrm{it}}
\end{gathered}
$$

Interpretation

As depicted in the five, it was discovered that cost of sales (COS) and operational cost (OPC) insignificantly affect return on asset (ROA) of the listed companies in Nigeria. The probability of the Random Effect Wald chi $^{2}{ }_{(2)}$ with $\rho$-value of 0.4641 indicated that responsibility accounting measured as cost of sales and operational cost insignificantly affect profitability measured as return on asset (ROA) of the listed companies in Nigeria

Table 5 without the control variable shows that cost of sales has negative effect of 0.00001 which indicate that $1 \%$ increase in cost of sales has insignificant negative effect of 0.00001 million naira on return on asset while operating cost has no effect of 0.0000 shows that $1 \%$ increase in operating cost has no effect on responsibility accounting.

The Adj $\mathrm{R}^{2}$ reflect 0.0089 which shows that the composition of responsibility accounting in ROA is $0.89 \%$ while the balance of $91.11 \%$ is represented by factors not captured in this model.

Decision

Based on the insignificant result of the Random Effect Wald $\mathrm{chi}^{2}{ }_{(2)}$ with $\rho$-value of 0.4641 which is greater than $5 \%$ significance level; this study accepts the null hypothesis Five which states that responsibility accounting has no significant effect on return on asset (ROA) of the listed companies in Nigeria and rejects the alternate hypothesis that responsibility accounting has significant effect on return on asset (ROA) of the listed companies in Nigeria. 
With Control Variable:

When firm size (FS) as control variable in model 5 to form model 6 , it was observed that at $5 \%$ chosen significant level, cost of sales (COS) and operational cost (OPC) insignificantly affect return on asset (ROA) while firm size (FS) exerted significant positive effect on ROA of the listed companies in Nigeria. This implies that as the size of firm changes by a unit, ROA of listed companies in Nigeria would increase by $23.9 \%$. The probability of the Random Effect Wald $\mathrm{chi}^{2}{ }_{(3)}$ with $\rho$-value of 0.782 which is greater than $5 \%$ significance level, also, the Adjusted R2 is 0.0399 which shows that the composition of responsibility accounting is $3.99 \%$ while the balance of $96.01 \%$ is represented by factors outside the model. This study accepts the null hypothesis Six which states the relationship between responsibility accounting and return on asset is significantly controlled by the firm size of listed companies in Nigeria. In view of the Fstatistics of 1.08 and P-value of $7.82<0.05$ level of significance adopted for this study

Discussion of Findings

The insignificant effect of cost of sales on return on asset obtained in this study negates the reports of Nyakuwanika et al [41]. Also with the results found by the studies of Owolabi and Obida [44]; Muneer et al [36] and Abebe and Abera [1], however supported the findings of Niresh and Velnampy [40] possible because of the variables nature of data used in both studies.

The negative finding of the effect of operating cost on return on asset is consistent with the negative result obtained in the study of Moigan [35]. However, all the results suggested the acceptance of the null hypothesis of no significance effect of responsibility accounting on return on assets in listed companies in Nigeria and concluded that there is no significant effect of responsibility accounting on return on assets in listed companies in Nigeria. This aligned with the report of Amutari [7] who found that responsibility accounting has significant effect on the profitability of the Kuwaiti oil companies and contradicts the findings of Akenbor and Nkem [5] and Nawaiseh er al [37].

\subsection{Implications of Findings}

Following the analysis, result and interpretation and the findings, this study could be beneficial to managers, investors, market analyst, policymakers, auditors, and the academia are concerned with quality of accounting information for decision making and economic values of responsibility accounting.

Top Management Staff: Since this study revealed that responsibility accounting significantly impacted on profitability, the managers should understand responsibility accounting properly, implement organizational strategies and insist on quality decisions by delegating authorities, to motivate unit centers to improve productivity and profitability. The strategic managers should insist on continuous improvements, stretch targets, restructure and reengineer and encourage autonomous work team towards achieving the organization profitability objective.
To Analysts and Capital Market Participants: The implications of this result suggest that the analysts and other equity market participants may find this information useful in making investment projections and improve financial market participation and investment choice in portfolio diversification and investment selections, since the study revealed that profitability is influenced by responsibility accounting.

To Investors: The findings of the study will be useful to investors when setting investment portfolio priorities in the midst of uncertainty and volatilities in the investment decisions, profitability is a major factor when investors want to make investment decisions.

To Financial Regulators: Financial regulators such as Securities and Exchange Commission (SEC), Central Bank of Nigeria $(\mathrm{CBN})$ and Financial Reporting Council of Nigeria (FRCN), will find this study to be useful to them when formulating accounting and financial standards, principles and guidelines in implementing responsibility accounting, performance appraisal and measuring components towards improving profitability in Nigerian companies desiring to implement responsibility accounting.

To Policy Markers: This study will be useful for policy makers, especially in readiness for economic policy formulation and possible defense mechanisms for a more stable investment environment using the significant effects of some of the firm's characteristics and responsibility accounting proxies employed in this study.

To Scholars and Researchers: This study also will be useful to scholars and the academia who are interested in research on responsibility accounting and profitability, thereby increasing the research data pool for further research work.

\section{Conclusion}

This study investigated the effect of responsibility accounting on profitability. It also established the controlling effects of firm size on the relationship between responsibility accounting and profitability. Responsibility accounting is proxy by cost of sales and operating cost, while profitability is proxy by net profit before tax, earnings per share and return on asset. The study concluded that responsibility accounting, controlling for firm size significantly affect profitability of listed companies in Nigeria.

\section{Recommendations}

Based on the findings and conclusion of this study, the following recommendations are useful to the managers, management as a whole, investors, market analysts, and policy makers:

i. Managers should boost their asset base as this is shown in the findings that firm with larger asset base were able to control their cost of sales and operational cost thus significantly influence their profitability level. It is reflected in this result that cost of sales negatively 
affect net profit before tax, hence, mangers should strive to take advantage of quantity discount thus reducing the cost of sales especially for inventories whish are not perishable in nature.

ii. The investors should critically and objectively study and understand the dynamics of responsibility accounting, the reported performances of companies implementing responsibility accounting and ensure that performance measures are established in the companies which they intend to invest for those companies implementing responsibility accounting and, that performance is measured while individuals are properly rewarded for good performance. This will guide investors and other capital market participants in making informed investment decisions and portfolios diversifications strategies particularly in time of investment uncertainties. Therefore investors and should pay more attention to the earnings consistency trend of the unit centers of the sampled companies.

iii. The management of listed companies should implement responsibility accounting and place emphasis on profitability in a profit center in order to satisfy the shareholders objective of wealth maximization

iv. Securities and Exchange Commission on Nigeria should enforce the management of listed companies to introduce financial strategy of implementing the measure of efficiency, effectiveness and economy so that responsibility accounting will work for them

v. The management of listed companies should use earnings per share as an annual measure to assess and appraise the sustainability of responsibility accounting

\section{References}

[1] Abebe, A. K., \& Abera, M. T. (2019). Determinants of financial performance; Evidence from Ethiopia insurance companies. Journal of Accounting, Finance and Auditing Studies, 5 (1), 155-172.

[2] Abo, N., \& Mohamad, H. (2010). The administrative accounting. $\left(1^{\text {st }} \mathrm{Ed}\right)$. Dar Wael, Amman Jordan.

[3] Adegbie, F. F., Olusanjo, O. R., \& Olaoye, A. S. (2018). Application of responsibility accounting to productivity evaluation in the Nigerian quoted companies. Journal of Advance Research in Business Management and Accounting, 4 (6), 1-24.

[4] Akeju, J. O. (2011). Financial accounting for beginners. (1 ${ }^{\text {st }}$ Ed). Shomolu, JBA Associates Ltd. Shomolu Lagos.

[5] Akenbor, C. O., \& Nkem, N. J. (2013). The effectiveness of responsibility accounting in evaluating Segment performance of manufacturing firms. Journal of Accounting Research and Practices, 2 (2), 103-112.

[6] Al-Nimer, M., \& Warrad, L. (2015). The impact of liquidity on Jordanian banks profitability. European Journal of Business and Management, 7 (1), 412-430.
[7] AlMutari, M. N. (2011). The effect of responsibility accounting on the profitability of Kuwaiti oil Companies. (MA Thesis) University of Middle East, Amman, Jordan.

[8] Alshomaly, I. Q. (2013). Performance evaluation and responsibility accounting. Journal of Research, 5 (2), 45-52.

[9] Berle, A. A., \& Means, G. C. (1932). The Modern corporation and private property. $\left(3^{\text {rd }} \mathrm{Ed}\right)$ New York: Harcourt, Brace \& World Publishers.

[10] Biswas, T. (2017). Responsibility accounting: A review of related literature. International Journal of Multidisciplinary Research and Development, 4 (8), 202-206.

[11] Bygrave, W. D., Hay, M., Ng, E., \& Reynolds, P. (2003). A study of informal investing in 29 Nations composing the global entrepreneur monitor: Venture capital. An International Journal of Entrepreneurial Finance, 5 (1), 101-116.

[12] Chartered Institute of Management Accountant (2015). Responsibility Accounting.

[13] Derbali, A., \& Jamel, L. (2018). Determinants of performance of Tunisia insurance companies: Case of life insurance. Journal of Business and Insurance, 2 (1), 25-39.

[14] Deloof, M. (2013). Does working capital management affect profitability of Belgian firms? Journal of Business and Finance Accounting, 30 (1), 573-587.

[15] Diamond, D. W. (1984). Financial intermediation and delegated monitoring. Review of Economic Studies 51 (166), 393.

[16] Dow, J., \& Gorton, G. (1997). Stock market efficiency and economic efficiency: Is there a connection? Journal of Finance, 2 (1), 1087-1129.

[17] Eliwa, Y. A. M. (2015). The Impact of earnings quality on aspects of capital markets: Evidence from UK listed firms. (Doctoral thesis). Heriot-Watt university school of management and languages http://www.ros.hw.ac.uk/bitstream/handle/10399/3005/EliwaY _0615_sml.pdf?sequence $=1$. Retrieved $1 / 05 / 2018$

[18] Fakir, A. A., Islam, M. Z., \& Miah, M. S. (2014). The Use of Responsibility Accounting in Textile Industry in Bangladesh. Journal of Business Studies, 35 (2), 261-273.

[19] Fowzia, R. (2011). Use of responsibility accounting and measure of the satisfaction level in service organizations in Bangladesh. International Reviews of Business Research, 7 (2), 53-67.

[20] Friebel, G., \& Raith, M. (2009). Resource Allocation and Firm Scope. ( $3^{\text {rd }}$ Ed). Center for Economic Research Journal, 2 (1), 220-221.

[21] Gharaibeh, B, (2008). The extent of the application of Jordanian Industrial Corporations companies, the responsibility accounting and its impact on profitability and operational efficiency, (Unpublished Master dissertation), University of Jordan, Amman, Jordan

[22] Gray, S. (2016). Responsibility accounting practices in India. International Conference on Multidisciplinary Research and Practice, 3 (1), 25-40.

[23] Goel, S., Mazzola, P., Phan, P. H., Pieper, T. M., \& Zachary, R. K. (2012). Strategy, ownership, governance, and sociopsychological perspectives on family businesses from around the world. Journal of Family Business Strategy, 3 (1), 54-65. 
[24] Hanini, A. (2013). The extent of implementing responsibility accounting features in the Jordanian banks. European Journal of Business and Management, 5 (1), 217-229.

[25] Harward, G., \& Upto, W. (1960). Introduction to Business Finance. $\left(1^{\text {st }}\right.$ Ed), New York. McGraw Hill, New York.

[26] Hifza, M. (2011). Determinants of insurance company's profitability: An analysis of insurance sector of Pakistan. Academic Research International, 1 (3), 23-45.

[27] Horngren, C. T. (2006). Accounting for management control an introduction, England, Prentice Hall, p. 277.

[28] Jensen, C., Meckling, H., (1976). Theory of the firm: managerial behavior, agency costs and ownership structure. Journal of Financial Economics, 3 (4), 305-360.

[29] Karasioghu, F., \& Gokturk, I. E. (2012). The application of responsibility accounting system with the scope of increasing efficiency in hospital business in Turkey. Journal of Finance 11 (1), 199-203.

[30] Kingsley, O. E. O., Endurance, O., Sunny, A. I., \& Ozele, E. (2014). Responsibility accounting: an overview. Journal of Business and Management, 16 (1), 73-79.

[31] Kishore, S. D., \& Ghosh, D. (2016). Analysis of motivation issues and link with profitability: Case study of entrepreneurial firms in a rural cluster in West Bengal, India. Business and Economic Journal, 7 (4), 21-39.

[32] Machdar, N. M. (2019). Impact of corporate governance on company's performance with sustainability reporting as an intervening variable in Indonesia. Advances in Economics, Business and Management Research, 1 (1), 23-35.

[33] Magablih, A. M. (2017). The reflection of social responsibility accounting application in the insurance companies. International Journal of Economics and Finance, 9 (7), 241-252.

[34] Makori, D. M., \& Jagongo, A. (2013). Environmental Accounting and Firm Profitability: An Empirical Analysis of Selected Firms Listed in Bombay Stock Exchange, India. International Journal of Humanities and Social Science, 3 (18), 248-256.

[35] Mojgan, S. (2012). Examining the role of responsibility accounting in organizational structure. American Academic \& Scholarly Research Journal, 4 (5), 401-432.

[36] Muneer, M, F, J., \& Farouq, A. A., Mohammed, A, R., \& Ata, M. A. (2015). The availability of components accounting responsibility in industrial companies in Aqaba City. European Scientific Journal, 8 (22), 58-62.

[37] Nawaiseh, M. E., Zeidan, A., Falahat, M., \& Otish, A. (2014). An empirical assessment of measuring the extent of implementing responsibility accounting rudiments in Jordanian industrial companies listed at Amman Stock Exchange. Advances in Management \& Applied Economics, 4 (1), 123-138.

[38] Nedles, B. E., Powers, M., \& Crosson, S. V. (2002). Financial and management accounting ( $3^{\text {rd }}$ Ed). Houghton Mifflin Company Boston, New York. ISBN: 0-618-10231-0

[39] Nibedita, D. (2018). Impact of corporate governance on financial performance: A study on DSE listed insurance companies in Bangladesh. Global Journal of Management and Business Research: Accounting and Auditing, 18 (2), 33-39.
[40] Niresh, J. A., \& Velnampy, T. (2014). Firm size and profitability: A study of listed manufacturing firms in Sri Lanka. International Journal of Business and Management, 9 (4), 112-125.

[41] Nyakuwanika, M., GutuG, J., Zhou, S., Tagwireyi, F., \& Chidoko, C. (2012). An analysis of effective responsibility accounting system strategies in the Zimbabwean Health Sector Research Journal of Finance and Accounting, 3 (8), 86-92.

[42] Ocansey, E. O. N. D., \& Enahoro, J. A. (2012). Determinant controllability of responsibility accounting in profit planning. Canadian Social Science, 8 (2), 91-95.

[43] Owino, P., (2017). Responsibility accounting in Ugandan public universities: Agency relation consideration. International Journal of Educational Policy Research and Revi. 4 (4), 62-71.

[44] Owolabi, S. A., Obida, S. S. (2012). Liquidity management and corporate profitability: Case study of selected manufacturing companies listed on the Nigerian Stock Exchange. Journal of Business Management Dynamics, 2 (2), $10-25$.

[45] Padachi, K. (2016). Trends in working capital management and its impact on firms' performance: Analysis of Mauritanian small manufacturing firms. International Review of Business Research Papers, 2 (2), 45-58.

[46] Pajrok A. (2014). Responsible accounting in the hospitality industry, Journal of Education culture and society. 5 (2), 5360 .

[47] Panda, B., \& Leepsa, N. M. (2017). Agency theory: Review of theory and evidence on problems and perspectives. Indian Journal of Corporate Governance, 10 (1), 74-95.

[48] Patel, A. T. (2012). Responsibility Accounting: A study in theory and Practice. Indian Journal of Applied Research, 3 (3), $1-2$.

[49] Rani, R., \& Rani M. (2015). The role of responsibility accounting in organizational structure, International journal of Science, Technology and Management, 41 (1), 185-190.

[50] Said, A. (2012). Comparing the change in efficiency of the Western and Islamic banking systems. Journal of Money, Investment and Banking ISSN 145-288X (8).

[51] Stilwell, J. (2015). Total capital efficiency: An economic theory of sustainability development. European Journal of Business and Social Sciences, 3 (3), 101-120

[52] Umobong, A. (2015). Assessing the impact of liquidity and profitability ratios on growth of profits in Pharmaceutical firms in Nigeria. European Journal Of Accounting, Auditing And Finance Research, 3 (10), 97-114.

[53] Yang, C., \& Modell, S. (2012). The economic sociology of responsibility accounting: A field study in a Chinese state owned enterprise. Manchester, New Helhi: Business School University of Manchester.

[54] Zahoor, H. J., \& Huma, R., Bader, A., \& Muhammad, F. N. (2015). Effect of financial leverage on performance of the firms: Empirical evidence from Pakistan. Journal of Economics and Business, 65 (1-2), 87-95.

[55] Zerbe, R. O. (2001). Economic efficiency in law and economics, Cheltenham, UK: Edward Elgar Publishing. 
[56] Zhai, J., \& Wang, Y. (2016). Accounting information quality, governance efficiency and capital investment choice. China Journal of Accounting Research, 2 (1), 55-79.
[57] Zimmerman, J. L. (2011). Accounting for decision making and control. $\left(2^{\text {nd }}\right.$ Ed) Singapore: Irwin McGraw-Hill Education. 